\title{
In Vitro Antileptospiral Activity of Trigona thoracia Propolis and its Synergistic Effects with Commonly Prescribed Antibiotics
}

\author{
Siti Radziah Ismail ${ }^{a}$, Salwani Ismail ${ }^{a}$, Zakuan Zainy Deris ${ }^{b}$ and Nabilah Ismail ${ }^{b^{*}}$ \\ ${ }^{a}$ Faculty of Medicine, Universiti Sultan Zainal Abidin (UniSZA), Medical Campus, Jalan Sultan Mahmud, 20400 \\ Kuala Terengganu, Terengganu, Malaysia. \\ bepartment of Medical Microbiology and Parasitology, School of Medical Sciences, Health Campus, \\ Universiti Sains Malaysia, 16150 Kubang Kerian, Kelantan, Malaysia.
}

\section{ABSTRACT}

Introduction: Trigona thoracica propolis is known to have antimicrobial properties, however its antileptospiral properties and its synergistic effects with commonly prescribed antibiotics are scarcely documented. This study aimed to evaluate the antileptospiral properties of Trigona thoracica against pathogenic Leptospira species (spp.) and to study its synergistic effects with commonly prescribed antibiotics. Materials and Methods: The tested Leptospira serovars were Australis, Bataviae, Canicola and Javanica. Aqueous extract propolis (AEP) and ethanolic extracts propolis (EEP) were used. Broth dilution methods were used to determine the Minimum Inhibitory Concentration (MIC), Minimum Bactericidal Concentration $(M B C)$ and the synergistic effects between the propolis and the tested antibiotics. The synergistic effects was evaluated by using the fractional inhibitory concentration (FIC) index. Morphological changes of the treated Leptospira were observed under a Scanning Electron Microscope (SEM). Results: The AEP and EEP were found to have antileptospiral properties against the tested Leptospira spp. The synergy result showed that only combination of AEP and penicillin G against serovar Australis has demonstrated synergistic effect with the FIC index of 0.38. Morphological study using SEM showed significant structural changes of the treated Leptospira spp. Conclusions: The result suggests that Trigona thoracica propolis could potentially be used as either a complimentary or an alternative therapeutic agent against pathogenic Leptospira spp.

KEYWORDS: Trigona thoracica, Antileptospira, Aqueous extract propolis, Ethanol extracts propolis

\section{INTRODUCTION}

Leptospirosis is the most widespread zoonotic disease caused by pathogenic Leptospira species, which belongs to the family leptospiracae. Leptospirosis occurs when pathogenic species are transmitted into the bloodstream of humans through cuts, skin abrasions or mucus membranes via direct contact with contaminated urine of animal reservoirs such as rodents and small mammals ${ }^{1}$ or indirect contact with contaminated water and soil. ${ }^{2}$ Patients

Corresponding author

Nabilah Ismail

Department of Medical Microbiology and

Parasitology,

School of Medical Sciences, Health Campus, Universiti Sains Malaysia, 16150 Kubang Kerian, Kelantan, Malaysia.

Tel No : +6097676302

Email : drnabilah@usm.my with severe leptospirosis are usually treated with intravenous penicillin while the mild cases are treated with oral doxycycline. ${ }^{3}$

Stingless bees are a group of small to medium sized bees, with vestigial stings, found in tropical and many subtropical parts of the world. One of the most common stingless bee is Trigona thoracica which produces less honey but higher quantity of propolis as compared to other bees ${ }^{4}$ and it is believed that their propolis is more potent than the honey produced by honey bees. ${ }^{5}$ Propolis from stingless bees have a wide spectrum of biological activities such as antiinflammatory, antiseptic, antitumor, antimicrobial, antifungal and antiviral properties. ${ }^{6,7}$ Yaghoubi et al. $^{8}$ has reported that Iranian propolis has high antimicrobial activity due to its high total phenolic acids and flavonoids contents. Jain et al. ${ }^{9}$ has 
revealed that flavonoids in propolis has an important role in antimicrobial activity. Propolis has reliable in vitro antibacterial activity against several gram positive and gram negative bacteria. ${ }^{5}$

Combinations of antibiotics and propolis extracts have been used to generate synergistic effects against bacteria. Stepanović et al. ${ }^{10}$ has reported that the combination of ethanolic extract propolis and selected antimicrobial agents has demonstrated significant synergistic effects against Salmonella Typhi. However, the antileptospiral properties of propolis and its synergistic effects with commonly prescribed antibiotics has scarcely been documented. This study aimed to evaluate the antileptospiral properties of Trigona thoracica propolis against pathogenic Leptospira spp. and to evaluate its synergistic effects with commonly prescribed antibiotics.

\section{METHODOLOGY}

\section{Propolis extraction and preparation}

This study used propolis produced by Trigona thoracica, which was supplied by the Min House Camp in Kubang Kerian, Kelantan, Malaysia. Before doing the extraction, the propolis sample was kept at $-20{ }^{\circ} \mathrm{C} .{ }^{11}$ The propolis was then cut into smaller pieces and blended. The powder form of propolis was then soaked into two different solvents namely aqueous and $70 \%$ ethanol at $30{ }^{\circ} \mathrm{C}$ in a shaker incubator for 14 days. Both solutions were filtered and the filtrate was evaporated using rotary evaporator. The aqueous extract propolis (AEP) was freeze-dried while ethanolic extract propolis (EEP) was dried using a hot plate.

AEP stock solution $(100 \mathrm{mg} / \mathrm{mL})$ was prepared by diluting $3.39 \mathrm{~g}$ of AEP in a powder form in $33.9 \mathrm{~mL}$ of $0.1 \%$ Dimethyl sulfoxide (DMSO) and $\mathrm{dH}_{2} \mathrm{O}$ solution. While for EEP, the stock solution $(100 \mathrm{mg} / \mathrm{mL})$ was prepared by diluting $3.39 \mathrm{~g}$ of EEP in $33.9 \mathrm{~mL}$ of $0.1 \%$ DMSO and $\mathrm{dH}_{2} \mathrm{O}$ solution. ${ }^{12}$

Inocula preparation of the pathogenic Leptospira spp. Four different serovars of Leptospira interrogans were used in this study. The serovars were Australis, Bataviae, Canicola and Javanica. They were obtained from the available stock cultures at the Microbiology Laboratory of the Department of Medical Microbiology and Parasitology, School of
Medical Sciences, Health Campus, University Sains Malaysia, Kelantan, Malaysia. The leptospires were subcultured in Ellinghausen McCullough, Johnson and Haris (EMJH) medium (Difco) at $30^{\circ} \mathrm{C}$ for 7 days with daily inspection of the growth of the organism. Indirect counting of the leptospires was done by measuring the optical density (OD) of the culture media containing growing leptospires by a spectrophotometer at $420 \mathrm{~nm}$ wavelength of OD 0.32 (approximately $1 \times 10^{8}$ cells $\left./ \mathrm{mL}\right)^{13}$. Then adjusted to reach $2 \times 10^{6}$ cells $/ \mathrm{mL}$ by adding EMJH or Leptospira inoculum. ${ }^{13}$ Direct counting of the organisms was performed under a dark field microscope using Petroff-Hausser counting chamber. ${ }^{14}$

\section{Preparation of the tested antibiotics}

The stock solution $(1 \mathrm{mg} / \mathrm{mL})$ of each tested antibiotic, such as doxycycline, ceftriaxone, and penicillin $\mathrm{G}$ was prepared by dissolving $1 \mathrm{mg}$ reagent grade of the antibiotic in a powder form in 1 $\mathrm{mL}$ sterile distilled water. The individual working solution of each antibiotic $(100 \mu \mathrm{g} / \mathrm{mL})$ was prepared by diluting $0.1 \mathrm{~mL}$ of the stock solution in $0.9 \mathrm{~mL}$ sterile distilled water.

\section{Susceptibility testing of the propolis extracts}

\section{Minimum inhibitory concentration}

The minimum inhibitory concentration (MIC) determination of the propolis extracts was performed by using broth microdilution technique. ${ }^{15}$ MIC was defined as the lowest concentration of the propolis that exhibits complete inhibition of the microbial growth ${ }^{16}$ as detected by the lack of visible turbidity ${ }^{11,17}$ and the lowest values of optical density. ${ }^{18}$

Two fold serial dilution of each AEP and EEP stock solution at the concentration of $100,50,25,12.5$, $6.25,3.13,1.57,0.78,0.39,0.20$ and $0.1 \mathrm{mg} / \mathrm{mL}$ were prepared in $100 \mu \mathrm{LMJH}$ medium in a sterile 96 well round bottom ELISA plate. A $100 \mu \mathrm{l}$ of leptospires inoculum $\left(2 \times 10^{6}\right.$ cells $\left./ \mathrm{mL}\right)$ was added to each test well and the suspension was mixed well. A well that contained a mixture of EMJH and leptospires inoculum without propolis extracts was used as a positive control well while the negative control well contain EMJH only. The plates was incubated at $30^{\circ} \mathrm{C}$ for 5 days. MIC results was taken as the lowest concentration of the propolis that 
inhibits the leptospiral growth observed under a dark field microscope ${ }^{19}$ and the lowest OD measured at $420 \mathrm{~nm}$ by ELISA reader. ${ }^{13}$ The tests were performed in duplicate.

\section{Minimum bactericidal concentration}

Minimum bactericidal concentration (MBC) was performed by subculturing the inoculum suspension from the MIC well onto EMJH agar. The inoculated EMJH agar was then incubated at $30{ }^{\circ} \mathrm{C}$ for 7 days. The MBC was defined as the least concentration showing no growth in the EMJH agar. ${ }^{20}$ The test was performed in duplicate.

\section{Susceptibility testing of the tested antibiotics}

\section{Minimum inhibitory concentration}

MIC determination of the antibiotics were performed using broth microdilution technique. ${ }^{15}$ MIC was defined as the lowest concentration of the antibiotics that exhibits complete inhibition of the microbial growth. ${ }^{16}$

Two fold serial dilution of the antibiotics at the concentration of $50,25,12.5,6.25,3.13,1.57,0.78$, $0.39,0.20$ and $0.1 \mu \mathrm{g} / \mathrm{mL}$ were prepared in $\mathrm{EMJH}$ medium in a sterile 96 -well round bottom ELISA plate. A $100 \mu$ l of leptospires inoculum $\left(2 \times 10^{6}\right.$ cells/ $\mathrm{mL}$ ) was added to each test well and the suspension was mixed well.

A well that contained a mixture of EMJH and leptospires inoculum without propolis extracts was used as a positive control well while the negative control well contain EMJH only. The plates were incubated at $30{ }^{\circ} \mathrm{C}$ for 5 days. MIC results was taken as the lowest concentration of the antibiotic that inhibits the leptospiral growth observed under a dark field microscope ${ }^{19}$ and the lowest OD measured at $420 \mathrm{~nm}$ by ELISA reader. ${ }^{13}$ The tests were performed in duplicate.

\section{Minimum bactericidal concentration}

$M B C$ was performed by subculturing the inoculum suspension from the MIC well onto EMJH agar. The inoculated EMJH agar was then incubated at $30{ }^{\circ} \mathrm{C}$ for 7 days. The $M B C$ was defined as the least concentration showing no growth in the EMJH agar. ${ }^{20}$ The test was performed in duplicate.

\section{Evaluation of the synergistic effects}

\section{MIC of the Propolis and antibiotics combination}

The synergistic effects between the combination of individual AEP and EEP with the tested antibiotics were studied using the checkerboard assay. ${ }^{21}$ Fifty microliters $(50 \mu \mathrm{l})$ of the two-fold serial dilution solutions $(100,50,25,12.5,6.25,3.13,1.57,0.78$, $0.39,0.20$ and $0.1 \mathrm{mg} / \mathrm{mL}$ ) of individual AEP and EEP was mixed with $50 \mu \mathrm{l}$ of tested antibiotics taking from two-fold serial dilution $(12.5,6.25,3.13,1.57$, $0.78,0.39, \quad 0.20$ and $0.1 \mu \mathrm{g} / \mathrm{mL}$ ) of antibiotic solutions. Hundred microliters $(100 \mu \mathrm{l})$ of Leptospira inoculum $\left(2 \times 10^{6}\right.$ cells $\left./ \mathrm{mL}\right)$ was then added into each well. The MIC of the combination was recorded as the lowest concentration of the combination solutions which inhibits the growth of leptospires. ${ }^{22}$

Synergy was evaluated by calculating the fractional inhibitory concentration (FIC) index. ${ }^{23}$ The FIC index was the mathematical expression used to represent the interaction between two antibiotics. ${ }^{24}$ Synergy was defined as a FIC $<0.5$, additive as $0.5<\mathrm{FIC}<1$, indifference as $1<\mathrm{FIC}<4$ and antagonism as a $\mathrm{FIC}>4 .{ }^{25}$ The following formula was used to interpret the synergy results. The sum of FIC that corresponds to MIC was calculated as follows ${ }^{25}$ :

$\begin{aligned} & \mathrm{FIC}=\mathrm{FIC} \mathrm{A}_{\mathrm{A}}+\mathrm{FIC}_{\mathrm{B}} \\ & \mathrm{FIC}_{\mathrm{A}}=\mathrm{FIC} \text { of propolis } \\ & \mathrm{FIC}_{\mathrm{B}}=\mathrm{FIC} \text { of antibiotic } \\ & \mathrm{MIC}_{\mathrm{A}}=\text { MIC of propolis individual } \\ & \mathrm{MIC}_{\mathrm{B}}=\text { MIC of antibiotic individual } \\ & \mathrm{C}_{\mathrm{A}}=\text { Concentration of propolis in } \\ & \mathrm{C}_{\mathrm{B}}=\text { Combination } \\ &\end{aligned}$

\section{Morphological study using SEM}

For the morphological study under SEM, the treated and untreated Leptospira interrogans serovar Australis were taken as a test sample and a control sample respectively. SEM Model FEG 450 was used to visualise the samples. Five tubes containing $5 \mathrm{~mL}$ of EEP at its MIC value at the concentration of $1.57 \mathrm{mg} /$ $\mathrm{mL}$ was mixed with $5 \mathrm{~mL}$ of leptospires inoculum. All of the test tubes were centrifuge at $4000 \mathrm{rpm}$ for 10 minutes. Primary fixation was carried out with McDowel Trump fixator for two hours. Then the 
samples were washed for two times with 0.1 M PBS buffer. Secondary fixation was carried out with $1 \%$ osmium tetroxide for an hour. Then the samples were washed again with distilled water for two times. Next, the samples were subjected to dehydration with ascending concentrations of acetone starting at $50 \%, 75 \%, 95 \%$ and $100 \%$ for 10 minutes each and two times for $100 \%$ acetone.

For full dehydration of samples, the samples were dehydrated two times with 100\% HMDS and then were allowed to dry. After fixing and drying, the samples were mounted to the SEM sample stub and then were coated with a thin layer of gold and were viewed under SEM.

\section{RESULT}

Numbers of the leptospires determined by direct and indirect counting

Numbers of the leptospires after direct and indirect counting were recorded in Table I. It was noted that the longer the incubation period the higher is the number of leptospires. Number of the leptospires by direct counting was in line with the indirect.

Table I: Number of leptospires by direct and indirect counting

\begin{tabular}{|c|c|c|c|c|c|c|c|c|c|c|}
\hline & \multirow{2}{*}{\multicolumn{2}{|c|}{ Method of counting }} & \multicolumn{7}{|c|}{ Duration of incubation } \\
\hline & & & & Day 1 & Day 2 & Day 3 & Day 4 & Day 5 & Day 6 & Day 7 \\
\hline \multirow{12}{*}{ 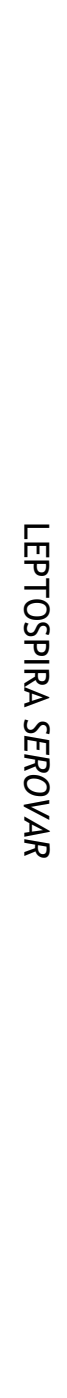 } & \multirow{3}{*}{ 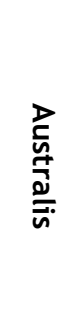 } & \multicolumn{2}{|c|}{$\begin{array}{l}\text { Direct Counting } \\
\text { (cells/mL) }\end{array}$} & $5.50 \times 10^{6}$ & $8.45 \times 10^{6}$ & $1.14 \times 10^{7}$ & $3.32 \times 10^{7}$ & $5.50 \times 10^{7}$ & $6.15 \times 10^{7}$ & $8.50 \times 10^{7}$ \\
\hline & & \multirow{2}{*}{$\begin{array}{l}\text { Indirect } \\
\text { counting }\end{array}$} & $(\mathrm{OD})$ & 0.042 & 0.073 & 0.103 & 0.149 & 0.194 & 0.273 & 0.322 \\
\hline & & & $\begin{array}{l}\text { (cells/ } \\
\mathrm{mL} \text { ) }\end{array}$ & $1.31 \times 10^{7}$ & $2.28 \times 10^{7}$ & $3.21 \times 10^{7}$ & $4.65 \times 10^{7}$ & $6.06 \times 10^{7}$ & $8.53 \times 10^{7}$ & $1.01 \times 10^{8}$ \\
\hline & \multirow{3}{*}{ 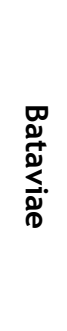 } & \multicolumn{2}{|c|}{$\begin{array}{l}\text { Direct Counting } \\
\text { (cells } / \mathrm{mL} \text { ) }\end{array}$} & $1.20 \times 10^{7}$ & $1.70 \times 10^{7}$ & $2.20 \times 10^{7}$ & $3.05 \times 10^{7}$ & $3.90 \times 10^{7}$ & $6.18 \times 10^{7}$ & $8.90 \times 10^{7}$ \\
\hline & & \multirow{2}{*}{$\begin{array}{l}\text { Indirect } \\
\text { counting }\end{array}$} & $(\mathrm{OD})$ & 0.042 & 0.083 & 0.123 & 0.171 & 0.218 & 0.278 & 0.314 \\
\hline & & & $\begin{array}{l}\text { (cells/ } \\
\mathrm{mL} \text { ) }\end{array}$ & $1.31 \times 10^{7}$ & $2.59 \times 10^{7}$ & $3.84 \times 10^{7}$ & $5.34 \times 10^{7}$ & $6.81 \times 10^{7}$ & $8.68 \times 10^{7}$ & $9.81 \times 10^{7}$ \\
\hline & \multirow{3}{*}{ 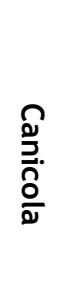 } & \multicolumn{2}{|c|}{$\begin{array}{l}\text { Direct Counting } \\
\text { (cells } / \mathrm{mL} \text { ) }\end{array}$} & $1.85 \times 10^{7}$ & $1.97 \times 10^{7}$ & $2.09 \times 10^{7}$ & $3.63 \times 10^{7}$ & $5.17 \times 10^{7}$ & $6.80 \times 10^{7}$ & $1.14 \times 10^{8}$ \\
\hline & & \multirow{2}{*}{$\begin{array}{l}\text { Indirect } \\
\text { counting }\end{array}$} & (OD) & 0.048 & 0.092 & 0.135 & 0.189 & 0.242 & 0.309 & 0.365 \\
\hline & & & $\begin{array}{l}\text { (cells/ } \\
\mathrm{mL} \text { ) }\end{array}$ & $1.50 \times 10^{7}$ & $2.87 \times 10^{7}$ & $4.21 \times 10^{7}$ & $5.90 \times 10^{7}$ & $7.56 \times 10^{7}$ & $9.65 \times 10^{7}$ & $1.14 \times 10^{8}$ \\
\hline & \multirow{3}{*}{ 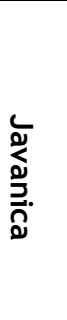 } & \multicolumn{2}{|c|}{$\begin{array}{l}\text { Direct Counting } \\
\text { (cells } / \mathrm{mL} \text { ) }\end{array}$} & $3.25 \times 10^{6}$ & $5.43 \times 10^{6}$ & $7.60 \times 10^{6}$ & $2.28 \times 10^{7}$ & $3.80 \times 10^{7}$ & $5.18 \times 10^{7}$ & $4.60 \times 10^{7}$ \\
\hline & & \multirow{2}{*}{$\begin{array}{l}\text { Indirect } \\
\text { counting }\end{array}$} & (OD) & 0.037 & 0.074 & 0.111 & 0.163 & 0.215 & 0.248 & 0.289 \\
\hline & & & $\begin{array}{l}\text { (cells/ } \\
\mathrm{mL} \text { ) }\end{array}$ & $1.15 \times 10^{7}$ & $2.31 \times 10^{7}$ & $3.46 \times 10^{7}$ & $5.09 \times 10^{7}$ & $6.71 \times 10^{7}$ & $7.75 \times 10^{7}$ & $9.03 \times 10^{7}$ \\
\hline
\end{tabular}

A spectrophotometer at $420 \mathrm{~nm}$ wavelength of OD 0.32 is approximately $1 \times 10^{8}$ cells $/ \mathrm{mL}^{13,38}$ 
Direct counting using Petroff Hausser was time and labor intensive and has the possibilities of increase in operator errors such as under counting and poor detection of leptospires. Based on the results in the Table I, serovar Canicola had the fastest multiplication of the organism and the slowest was serovar Javanica. The difficulty in the isolation of the leptospires and the slow growth of the organism made the culture technique time consuming and laborious.

\section{MIC and MBC of AEP, EEP and tested antibiotics}

The MIC and MBC results of AEP, EEP and tested antibiotics against Leptospira spp were shown in Table II. The AEP and EEP were found to have antileptospiral properties against the tested leptospiral serovars. The MIC of AEP against all of the tested serovars was $6.25 \mathrm{mg} / \mathrm{mL}$ while the $M B C$ of the AEP against serovar Australis was $25 \mathrm{mg} / \mathrm{mL}$ and 12.5 $\mathrm{mg} / \mathrm{mL}$ for other tested serovars.

The MIC of EEP against serovar Bataviae was $0.79 \mathrm{mg} /$ $\mathrm{mL}$ while the MICs for the other serovars were 1.57 $\mathrm{mg} / \mathrm{mL}$. The $M B C$ of the EEP against all of the tested serovar was $1.57 \mathrm{mg} / \mathrm{mL}$. Based on these results, EEP has a higher antileptospiral properties compared to AEP.

The MIC and MBC of the tested penicillin G, doxycycline, and ceftriaxone against all of the tested serovars were $0.39 \mu \mathrm{g} / \mathrm{mL}, \quad 0.78 \mu \mathrm{g} / \mathrm{mL} ; 3.13$ $\mu \mathrm{g} / \mathrm{mL}, 6.25 \mu \mathrm{g} / \mathrm{mL}$; and $0.20 \mu \mathrm{g} / \mathrm{mL}, 0.39 \mu \mathrm{g} / \mathrm{mL}$ respectively. Based on these results, ceftriaxone has the highest antileptospiral properties compared to other tested antibiotics.

Table II: MIC and MBC values of AEP, EEP and tested antibiotics against Leptospira spp

\begin{tabular}{|c|c|c|c|c|c|c|c|c|c|c|}
\hline \multirow{3}{*}{$\begin{array}{l}\text { LEPTOSPIRA } \\
\text { SEROVAR }\end{array}$} & \multicolumn{4}{|c|}{$\begin{array}{l}\text { Propolis Extract } \\
\quad(\mathrm{mg} / \mathrm{mL})\end{array}$} & \multicolumn{6}{|c|}{$\begin{array}{l}\text { Antibiotics } \\
(\mu \mathrm{g} / \mathrm{mL})\end{array}$} \\
\hline & \multicolumn{2}{|c|}{ AEP } & \multicolumn{2}{|c|}{ EEP } & \multicolumn{2}{|c|}{ Penicillin G } & \multicolumn{2}{|c|}{ Doxycycline } & \multicolumn{2}{|c|}{ Ceftriaxone } \\
\hline & MIC & $M B C$ & MIC & $M B C$ & MIC & $M B C$ & MIC & $M B C$ & MIC & $M B C$ \\
\hline Austrutis & 6.25 & 25.0 & 1.57 & 1.57 & 0.39 & 0.78 & 3.13 & 6.25 & 0.20 & 0.39 \\
\hline Bataviae & 6.25 & 12.5 & 0.79 & 1.57 & 0.39 & 0.78 & 3.13 & 6.25 & 0.20 & 0.39 \\
\hline Canicola & 6.25 & 12.5 & 1.57 & 1.57 & 0.39 & 0.78 & 3.13 & 6.25 & 0.20 & 0.39 \\
\hline Javanica & 6.25 & 12.5 & 1.57 & 1.57 & 0.39 & 0.78 & 3.13 & 6.25 & 0.20 & 0.39 \\
\hline
\end{tabular}

\section{Synergistic test}

The synergy result in Table III showed that only the combination of AEP and penicillin $G$ against serovar Australis has demonstrated synergistic effect with the FIC index of 0.38 . The additive effects (FIC index more than 0.5 and less than 1 ) were detected in the combination of AEP and penicillin $G$ against serovar Bataviae and Canicola; the combination of AEP and doxycycline against Bataviae and Canicola; and the combination of EEP and doxycycline against Australis. The rest of the combinations however demonstrated indifference effect (FIC more than 1 and less than 4) and none of the combinations showed the antagonistic effects (FIC more 4).

\section{Morphological changes of the treated leptospires}

The EEP-treated leptospires had shown significant morphological changes when observed under SEM compared to the untreated leptospires. The untreated leptospires at $30000 x$ magnification has characteristically helical structure with the presence of hooks at both ends of the organism (Figure 1). The treated leptospires at 30 000x (Figure 2a), 60 000x (Figure 2b) and 120 000x (Figure 2c) magnification however became less spiral, appeared flattened and shorten, and the hooks at both ends of the organism were absent. 


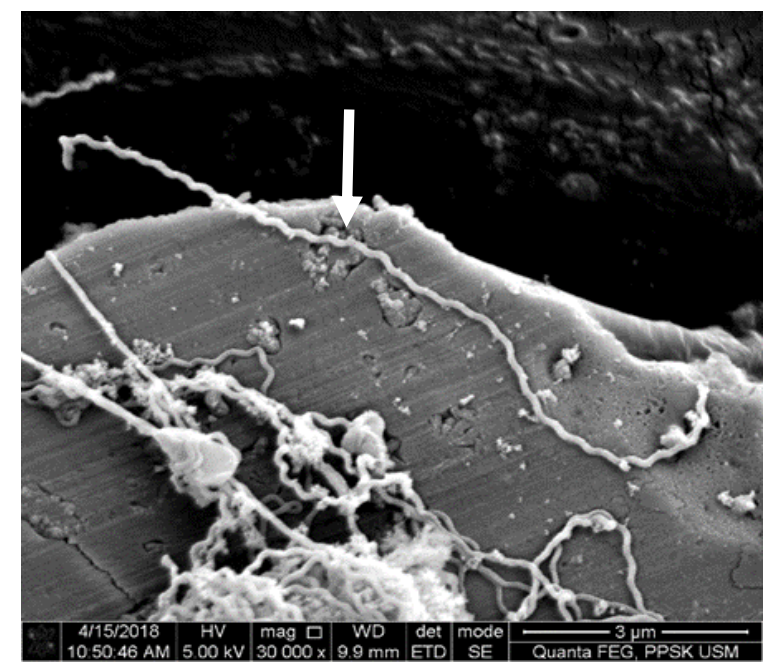

Figure 1: SEM micrograph of untreated Leptospira spp serovar Australis under scanning electron microscope (SEM) with $5 \mathrm{kV}$, at magnification $30000 x$. The untreated leptspires has characteristically helical structure with the presence of hooks noted at both ends of the leptospires.

\section{DISCUSSION AND CONCLUSION}

Both AEP and EEP have antileptospiral properties against pathogenic Leptospira spp. The properties were found to be higher in EEP compared to AEP. This is in line with the studies done by Park \& Ikegaki ${ }^{26}$ and Hendi et al. ${ }^{27}$ who have reported that EEP has a higher antimicrobial activities compared to AEP. Few studies on the antimicrobial activity of EEP showed a positive correlation between flavonoids content and the antibacterial properties of EEP. ${ }^{8}$ Al Ani et al. ${ }^{28}$ has investigated that EEP has many chemical substances such as flavonoids and polyphenols that contributed to the higher antibacterial properties compared to AEP.

Propolis have various mechanisms of action as an antibacteria including inhibition of bacterial cell division, disruption of bacterial cell walls and cytoplasmic membranes, inhibition of bacterial motility, bacterial enzyme inactivation, bacteriolysis, and bacterial protein synthesis inhibition. ${ }^{29}$ Bankova et al..$^{30}$ indicated that propolis and some of its cinnamic acid derivatives and flavonoids were responsible for uncoupling the energy transducing cytoplasmic membrane inhibiting bacterial motility, which might contribute to the antibacterial action. In this study, serovar Bataviae was found to be the most sensitive serovar to EEP compared to the serovar Australis, Canicola and Javanica. In contrast, Vedhagiri et al. ${ }^{31}$ and Seesom et al. $^{22}$ have found no significant difference in term of sensitivity of serovar Bataviae compared to other tested serovars.
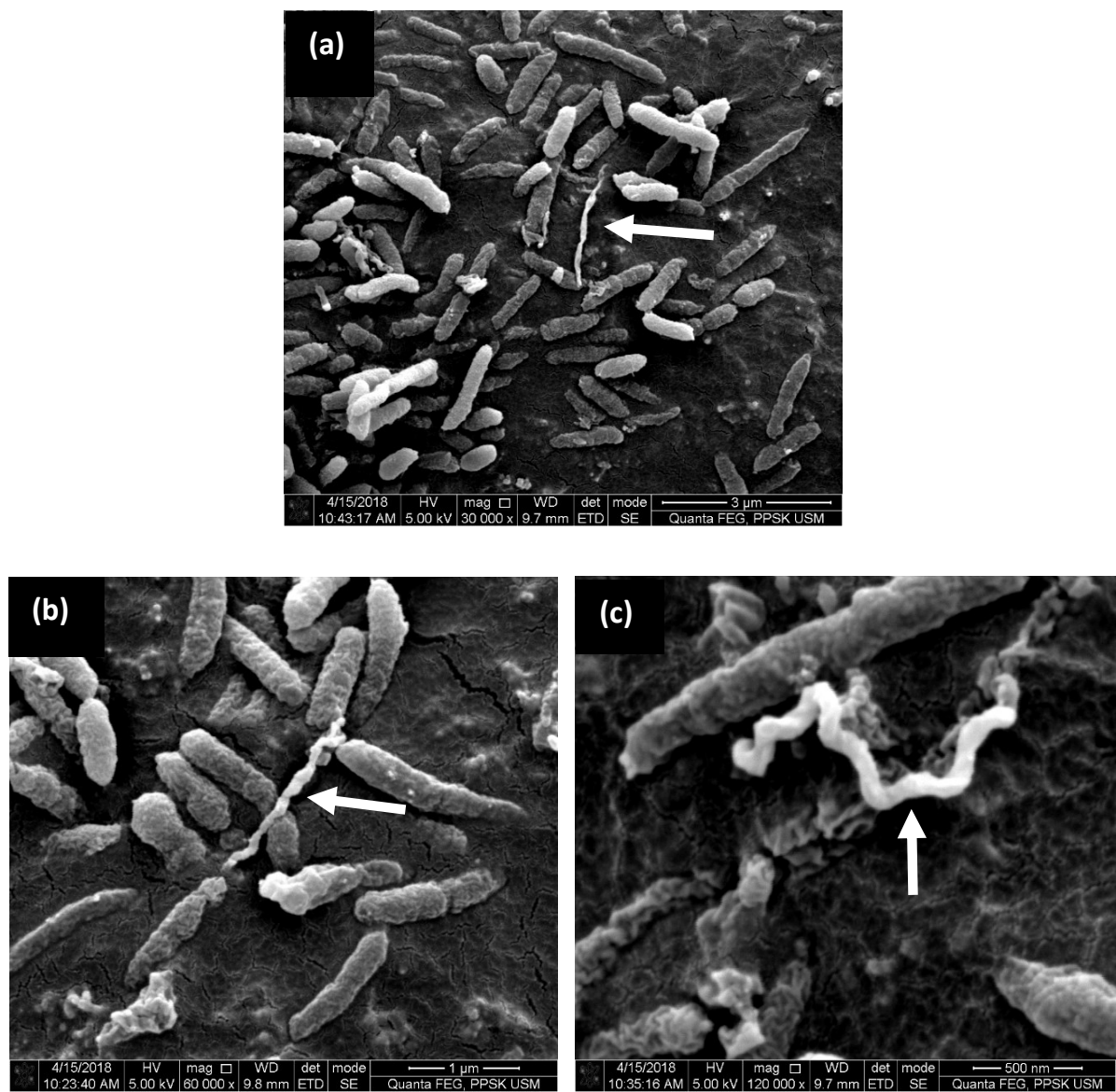

Figure 2: SEM micrograph of treated Leptospira spp serovar Australis with EEP with 5 kV (a) at magnification $30000 \mathrm{x}(\mathrm{b})$ at magnification $60000 \mathrm{x}$ and (c) at magnification $120000 \mathrm{x}$. The treated leptospires became less spiral, appeared flattened and shorten and the hooks at both ends of the organism were absent. 
Table III: Synergistic effect of propolis extract and antibiotics against leptospires

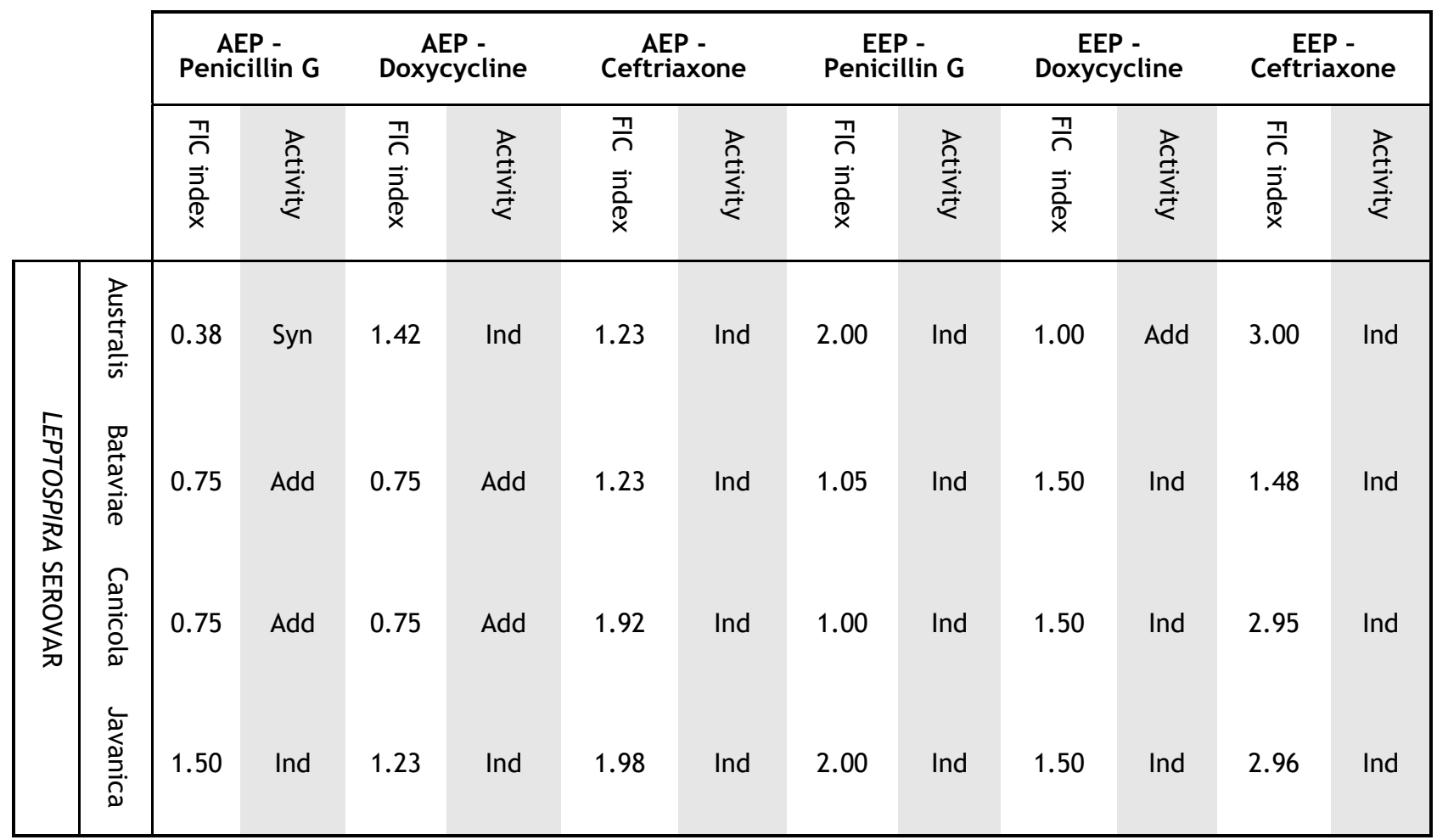

Syn; $<0.5$, Add; $>0.5$ and $\leq 1.0$, Ind $>1$ and $\leq 4$; Ant $>4$

Significant synergistic effect was demonstrated in the combination of AEP and penicillin $G$ against serovar Australis. It indicates that propolis extraction when used in combination with antibiotic has a potential to amplify the actions of antibiotics. ${ }^{8,29,32}$ Reported mechanism of action when propolis is combined with antibiotic including destruction of bacterial ribosomes. ${ }^{33}$ Bankova et al. $^{30}$ has reported that propolis and some of its cinnamic acid derivatives and flavonoids were responsible for uncoupling the energy transducing cytoplasmic membrane inhibiting bacterial motility, which might contribute to the antibacterial action. Combination of AEP with penicillin $G$ enhanced antileptospiral efficacy where propolis seemed to aid the beta-lactam antibiotic in penicillin binding protein (PBP) inhibition resulting in the destruction of bacterial wall. ${ }^{34}$

There was no similar study looking at the synergy effects of propolis extracts and antibiotics against Leptospira spp. in the past. However in 2013, Seesom et al. $^{22}$ has reported the synergy effect of the combination of penicillin $G$ and $\gamma$-mangostin against L. interrogans serovar Javanica, Autumnalis, and Bataviae with the FIC index of $0.04,0.50$, and 0.52 , respectively.
The role of penicillin is inhibition of peptidoglycan formation by binding to transpeptidases ${ }^{35}$ while propolis with some of its chemical compositions responsible for uncoupling the energy transducing cytoplasmic membrane. ${ }^{30}$

The EEP-treated leptospires were found to have significant morphological changes when observed under SEM compared to the untreated leptospires. Mirzoeva, Grishanin, \& Calder $^{36}$ reported that flavonoids in propolis disrupted the cytoplasmic membrane and cell wall of bacteria. This mechanism may enhance the morphological changes of the treated leptospires. Moreover, besides flavonoids, phenolic acids could also lead to the disintegration of the bacterial outer membrane. ${ }^{37}$

In conclusion, the results of this study suggest that Trigona thoracica propolis could potentially be used as either a complimentary or an alternative therapeutic agent against pathogenic Leptospira spp. infection.

\section{CONFLICT OF INTEREST}

The research was conducted in the absence of any commercial or financial relationships that could be seen as a potential conflict of interest. 


\section{ACKNOWLEDGEMENTS}

The authors are thankful to every person for their valuable technical supports and stimulating discussion to carry out this work.

\section{REFERENCE}

1. Benacer D, Woh PY, Nursheena S, Zain M, Amran F, Thong KL. Pathogenic and Saprophytic Leptospira Species in Water and Soils from Selected Urban Sites in Peninsular Malaysia. Microbes Env [Internet]. 2013 [cited 2018 Jul 15];28(1):135-40. Available from: https:// www.jstage.jst.go.jp/browse/jsme2

2. Levett PN. Leptospirosis. Clin Microbiol. 2001;14 (2):296-326.

3. Levett PN, Haake DA. Leptospira Species (Leptospirosis). In: Mandell, Douglas, and Bennett's Principles and Practice of Infectious Diseases. 2010. p. 1-8.

4. Yuliana ND, Wijaya CH, Nasrullah N. Classification of Trigona spp bee propolis from four regions in Indonesia using FTIR metabolomics approach. 13th Asean Food Conf 2013. 2013;(September):9-11.

5. Ibrahim N, Zakaria AJ, Ismail Z, Mohd KS. Antibacterial and phenolic content of propolis produced by two Malaysian stingless bees, Heterotrigona itama and Geniotrigona thoracica. Int J Pharmacogn Phytochem Res. 2016;8(1):156 $-61$.

6. Waldner-Tomic N, Vanni R, Belibasakis G, Thurnheer T, Attin T, Schmidlin P. The in Vitro Antimicrobial Efficacy of Propolis against Four Oral Pathogens: A Review. Dent J [Internet]. 2014;2(3):85-97. Available from: http:// www.mdpi.com/2304-6767/2/3/85/

7. Selvan A, Prabhu T. Extraction Of Propolis From Beehives And Characterization Of Its Constituents And Medicinal Properties. Int J Adv Eng Technol. 2010;।(lii):50-3.

8. Yaghoubi SMJ, Ghorbani G., Soleimanian ZS, Satari R. Antimicrobial activity of Iranian propolis and its chemical composition. DARU J Pharm Sci. 2007;

9. Jain S, Rai R, Sharma V, Batra M. Propolis in Oral Healthr: A Natural Remedy. World J Pharm Sci. 2013;2(1):90-4.

10. Stepanović S, Antić N, Dakić I, Švabić-Vlahović M. In vitro antimicrobial activity of propolis and synergism between propolis and antimicrobial drugs. Microbiol Res [Internet]. 2003 Jan 1 [cited 2018 Mar 14];158(4):353-7. Available from: https://www.sciencedirect.com/science/ article/pii/S0944501304701391

11. Shehu A, Ismail S, Rohin MAK, Harun A, Aziz AA, Haque M. Antifungal properties of Malaysian tualang honey and stingless bee propolis against Candida albicans and Cryptococcus neoformans. J Appl Pharm Sci. 2016;6(2):044-50.

12. Asawahame $C$, Sutjarittangtham $K$, Eitssayeam $S$, Tragoolpua $Y$, Sirithunyalug $B$, Sirithunyalug $J$. Antibacterial activity and inhibition of adherence of Streptococcus mutans by propolis electrospun fibers. AAPS PharmSciTech [Internet]. 2015 Feb [cited 2018 Jul 23];16 (1):182-91. Available from: http:// www.ncbi.nlm.nih.gov/pubmed/25245331

13. Moreno LZ, Miraglia F, Lilenbaum W, Neto JS, Freitas JC, Morais ZM, et al. Profiling of Leptospira interrogans, L. santarosai, L. meyeri and L. borgpetersenii by SE-AFLP, PFGE and susceptibility testing-a continuous attempt at species and serovar differentiation. Emerg Microbes Infect [Internet]. 2016;5(3):e17. Available from: http://www.nature.com/ doifinder/10.1038/emi.2016.16

14. Humberd CM, Murray CK, Stuart SK, Reeb BA, Hospenthal DR. Short report: Enumerating leptospires using the Coulter counter. Am J Trop Med Hyg. 2005;73(5):962-3.

15. Murray CK, Hospenthal DR. Broth Microdilution Susceptibility Testing for Leptospira spp. Antimicrob Agents Chemother [Internet]. 2004;48(5):1548-52. Available from: http:// www.scopus.com/inward/record.url?eid=2-s2.02142805904\&partnerID=40\&md5=78c3fe32e218b aedba4b220e3157c0b0

16. Andrews JM, Andrews JM. Determination of minimum inhibitory concentrations. J Antimicrob Chemother. 2001;48 Suppl 1:5-16.

17. Arslan $\mathrm{S}$, Ozbilge $\mathrm{H}$, Kaya EG, Er O. In vitro antimicrobial activity of propolis, BioPure MTAD, sodium hypochlorite, and chlorhexidine on $\mathrm{E}$. faecalis and C. Albicans. Saudi Med J. 2011;90 (March):479-83.

18. Banjara RA, Jadhav SK, Bhoite SA. MIC for determination of antibacterial activity of Di-2ethylaniline phosphate. J Chem Pharm Res [Internet]. 2012 [cited 2018 Sep 2];4(1):648-52. Available from: http://www.jocpr.com/ articles/mic-for-determination-of-antibacterialactivity-of-di2ethylaniline-phosphate.pdf 19. Natarajaseenivasan K, Sivalingam R. 
Experimental leptospirosis in laboratory mice and rats. J Commun Dis. 1997;

20. Ristivojević P, Dimkić I, Trifković J, Berić T, Vovk I, Milojković-Opsenica D, et al.

Antimicrobial Activity of Serbian Propolis

Evaluated by Means of MIC, HPTLC,

Bioautography and Chemometrics. 2016 [cited

2018 Aug 12]; Available from:

www.mpn.gov.rs/.

21. Speciale A, Musumeci R. Antibacterial Activity of Propolis and Its Activc Principles Alone and in Combination with Macrolides, Beta - lactams and Fluoroquinolones Against Microorganisms Responsible for Respiratoria; Infections. J Chemother [Internet]. 2006 [cited 2018 Mar 14];18(2):164-71. Available from: https:// www.researchgate.net/profile/Maria_Catania/ publication/7045775_Antibacterial_Activity_of_ Propolis_and_Its_Active_Principles_Alone_and_i n_Combination_with_Macrolides_Betalactams_and_Fluoroquinolones_Against_Microorg anisms_Responsible_for_Respirato

22. Seesom W, Jaratrungtawee A, Suksamrarn S, Mekseepralard C, Ratananukul P, Sukhumsirichart W. Antileptospiral activity of xanthones from Garcinia mangostanaand synergy of gamma-mangostin with penicillin $\mathrm{G}$. BMC Complement Altern Med [Internet]. 2013;13 (1):182. Available from: http:// bmccomplementalternmed.biomedcentral.com/ articles/10.1186/1472-6882-13-182

23. Odds FC. Synergy, antagonism, and what the chequerboard puts between them. J Antimicrob Chemother [Internet]. 2003;52(1):1-1. Available from: https://academic.oup.com/jac/articlelookup/doi/10.1093/jac/dkg301

24. Hsieh MH, Yu CM, Yu VL, Chow JW. Synergy assessed by checkerboard. Diagn Microbiol Infect Dis [Internet]. 1993 May 1 [cited 2018 Aug 7];16(4):343-9. Available from: https:// www.sciencedirect.com/science/article/ pii/073288939390087N?via\%3Dihub

25. Meletiadis J, Pournaras S, Roilides E, Walsh TJ. Defining fractional inhibitory concentration index cutoffs for additive interactions based on self-drug additive combinations, Monte Carlo simulation analysis, and in vitro-in vivo correlation data for antifungal drug combinations against Aspergillus fumi. Antimicrob Agents Chemother. 2010;54(2):6029.
26. Park YK, Ikegaki M. Preparation of Water and Ethanolic Extracta of Propolis and Evaluation of the preparations. Biosci Biotechnol Biochem. 1998;62(11):2230-2.

27. Hendi NKK, Naher HS, Al-Charrakh AH. In vitro antibacterial and antifungal activity of Iraqi propolis. J Med Plants Res [Internet]. 2011 [cited 2018 Jul 26];5(20):5058-66. Available from: http://www.academicjournals.org/JMPR

28. AL-Ani I, Zimmermann S, Reichling J, Wink M. Antimicrobial Activities of European Propolis Collected from Various Geographic Origins Alone and in Combination with Antibiotics. Medicines [Internet]. 2018;5(1):2. Available from: http://www.mdpi.com/2305-6320/5/1/2

29. Fernandes Júnior $A$, Cristina Balestrin $E$, Elaine Cristina Betoni J, de Oliveira Orsi R, de Lourdes Ribeiro de Souza da Cunha M, Cezar Montelli A. Propolis: anti-Staphylococcus aureus activity and synergism with antimicrobial [Internet]. Vol. 100, Mem Inst Oswaldo Cruz, Rio de Janeiro. 2005 [cited 2018 Aug 14]. Available from: http://www.scielo.br/pdf/mioc/v100n5/ v100n5a18.pdf

30. Bankova V, De Castro SL, Marcucci MC. Propolis: recent advances in chemistry and plant origin. Apidologie. 2000;

31. Vedhagiri K, Manilal A, Valliyammai T, Shanmughapriya S, Sujith S, Selvin J, et al. Antimicrobial potential of a marine seaweed Asparagopsis taxiformis against Leptospira javanica isolates of rodent reservoirs. Ann Microbiol. 2009;59(3):431-7.

32. Hazem A, Popescu CV, Crișan I, Popa M, Chifiriuc MC, Pircalabioru GG, et al. Antibacterial efficiency of five propolis extracts on planktonic and adherent microbial strains. Farmacia. 2017;65(5):813-8.

33. Orsi RO, Fernandes A, Bankova V, Sforcin JM. The effects of Brazilian and Bulgarian propolis in vitro against Salmonella Typhi and their synergism with antibiotics acting on the ribosome. Nat Prod Res [Internet]. $2012 \mathrm{Mar}$ [cited 2018 Aug 14];26(5):430-7. Available from: http://www.ncbi.nlm.nih.gov/ pubmed/21660841

34. de Oliveira Orsi R, Maurício Sforcin J, Regina Cunha Funari S, Fernandes Junior A, Bankova V. SYNERGISTIC EFFECT OF PROPOLIS AND ANTIBIOTICS ON THE SALMONELLA TYPHI. Brazilian J Microbiol [Internet]. 2006 [cited 2018 
Oct 14];37:108-12. Available from: http:// www.scielo.br/pdf/bjm/v37n2/arq02.pdf

35. Brenot A, Trott D, Girons I Saint, Zuerner R. Penicillin-Binding Proteins in Leptospira interrogans. Antimicrob Agents Chemother. 2001;45(3):870-7.

36. Mirzoeva OK, Grishanin RN, Calder PC.

Antimicrobial action of propolis and some of its components: the effects on growth, membrane potential and motility of bacteria. Microbiol Res [Internet]. 1997 Sep [cited 2018 Aug 6];152 (3):239-46. Available from: http:// www.ncbi.nlm.nih.gov/pubmed/9352659

37. Nohynek LJ, Alakomi H, Kähkönen MP, Heinonen M, Ilkka M, Puupponen-pimiä RH, et al. Berry Phenolics $\square$ : Antimicrobial Properties and Mechanisms of Action Against Severe Human Pathogens Berry Phenolics $\square$ : Antimicrobial Properties and Mechanisms of Action Against Severe Human Pathogens. Nutr Cancer. 2006;54 (1)(July 2015):37-41.

38. Miraglia F, Matsuo M, Morais ZM, Dellagostin OA, Seixas FK, Freitas JC, et al. Molecular characterization, serotyping, and antibiotic susceptibility profile of Leptospira interrogans serovar Copenhageni isolates from Brazil. Diagn Microbiol Infect Dis [Internet]. 2013;77(3):195-9. Available from: http://dx.doi.org/10.1016/ j.diagmicrobio.2013.08.003 